\title{
EDitorial
}

\section{O Mundo Mágico da Urologia}

A explosão tecnológica ocorrida nas duas últimas décadas atingiu de forma impensável a ciência médica, revolucionando seus métodos de ensino, a pesquisa, a assistência e deixando atônitos os mais atrevidos futuristas. Nesse período, alterações na sequência de inofensivas bases nitrogenadas passaram a explicar as mais simples e as mais tenebrosas doenças; possantes máquinas começaram a navegar pela intimidade do corpo humano, desvendando segredos que, sem diagnóstico, tolhiam existências; minúsculos genes puderam ser inseridos em células arredias, nelas produzindo metamorfoses nunca antes imaginadas; uma nova classe de "cirurgiões moleculares" anunciaram intervenções corretivas sobre fragmentos defeituosos de DNA, restaurando a vida; robôs amistosos, incansáveis, quase infalíveis e recheados de informações, estão ameaçando a existência dos doutores, assolados pelas imperfeições e angústias que envolvem a natureza humana.

Para poder continuar dominando o conhecimento e serem capazes de exercer a medicina na sua dimensão maior, os profissionais da saúde se juntaram e se especializaram. Dentro desse contexto floresceu a moderna Urologia, apoiada nesses avanços tecnológicos e conduzida por pessoas de imenso valor pessoal e determinação, que colocaram a especialidade num patamar de atuação clínica que supera a maioria das outras especialidades médicas. Afinal, que outro setor da medicina permite que os seus principais protagonistas, os urologistas, num mesmo dia aliviem a obstrução uretral de um rei, extirpem o tumor letal de um mendigo, mudem o sexo de uma criança, eliminem as dores, por cálculos ou infecções, de uma jovem donzela; ou reponham um novo órgão em seres privados de seus originais?

Tudo isto para dizer que a Urologia e os urologistas são especiais e para reverenciar aqueles que tornaram essa especialidade grandiosa. Incluindo os membros da nossa Instituição, que com o brilho intelectual e a simplicidade que caracteriza os homens de valor, aceitaram discorrer sobre os 12 temas, que reunidos neste número especial da Revista de Medicina da FMUSP, mostram um pouco do mundo mágico da Urologia. 